\title{
Fluctuating asymmetry of some head structures and its possible causes
}

\author{
Elżbieta Żadzińska \\ Chair of Anthropology, University of Łódź, Banacha 12/16, 90-237 Łódź, \\ Poland; E-mail: elzbietz@biol.uni.lodz.pl
}

\begin{abstract}
The analysis of eight cephalometric paired characters of 1236 children aged 7 to 10 was carried out. The standardized variance of differences between right and left character values (R-L) and the correlations between right and left values of same individuals were used to assess the fluctuating asymmetry (FA) level of each character and each individual. The highest values of FA were observed for the width of the wings of the nose (ala) (al-sn) and for the length of the nostrils (na-np), and the lowest for the length of the auricle ( $(s a-s b a)$ and length of the mandibular body (go-gn). Using the multiple regression the associations between the FA of the head and characteristics of individuals at birth as well as selected prenatal factors were estimated. These variables as a complex explain about $8 \%$ of the FA variability. Heavier newborns with bigger head and smaller chest circumference are characterized by more symmetric faces. Among the analyzed prenatal factors the declared alcohol consumption by the mother and smoking cigarettes by the father increased the FA level of a child's head.
\end{abstract}

KEY WORDS developmental stability, cephalometry, prenatal factors

Prz. Antropol.-Anthropol. Rev. (2003), vol. 66, pp. 39-54, Figs. 2, Tables 7. ISBN 8386969-92-X, ISSN 0033-2003

\section{Introduction}

Humans like all chordates, are characterized by bilateral symmetry of the body. Paired organs develop at a very early stage of embryonic life symmetrical to the main axis of the body, whose direction is "determined" at the cellular level by the homeobox genes (HOX-A, HOX-B, HOX-C and HOX-D) and the Hedgehog signal proteins [TABIN and
MCMAHON 1997, GELLON and MC GINNIS 1998]. The HOX gene family plays essential role in morphogenesis of the vertebrates' embryos providing the first necessary "instruction" concerning cellular development of particular regions [NUNES et al. 2003]. Signals determined by the genes (and then transmitted by the Hedgehog proteins) decide also the shape and growth direction of paired characters. Despite the precise 
molecular mechanisms that theoretically assure an equal development of the right and left sides [MøLLER and MANNING 2003], paired structures are almost never perfectly identical, but show some degree of asymmetry which usually consists of three components: directional and fluctuating asymmetry, and, extremely rarely, antisymmetry.

Directional asymmetry occurs when differences between the character of the right and left side (R - L) show constant direction, and their population distribution reveals apparent skewness [Møller and SwadDle 1997, POLAK 2003]. The shape of paired organs both of the right and the left side of the body is determined by the same genes which decide the apparent and systematic predominance of right or left measurement. There is a number of examples of such genetically programmed asymmetries characteristic for the human body, e.g., the left brain hemisphere is larger than the right one; the right lung is divided into three lobes and has a slightly larger volume than the bilobar right one; left teeth are (according to MIZOGUCHI [1988, 1990]) slightly more robust than the right ones; the left iliac crest is positioned slightly higher than the right one [DANGERFIELD 1994]; the right upper limb is about $10 \mathrm{~mm}$ longer than the left one and has greater circumferences and wider epiphyses of long bones; the left lower limb is $12 \mathrm{~mm}$ longer than the right one [FUDALI and GRALLA 1972, HENNEBERG 1974].

Fluctuating asymmetry has a different aetiology: Slight deviations from the symmetry (the average of the differences between the left and right measurements does not statistically differ from zero) show no particular direction but fluctuate gradually, sometimes deviating to either side within a given population. Increased fluctuating asymmetry of paired structures is considered to be an effect of the negative influence of exogenous factors on a developing organism. It depends not only on the kind, intensity and duration of the stressor, but also on the ability of an individual to stabilize development in adverse conditions [BARDEN 1980, HEIKINEN and Alvesalo 2001]. According to MøLlER and SWADDLE [1997, p. 16] "antisymmetry occurs when one side of a character is larger than the other, but there is no handed-bias as to which side will be larger. Therefore, it is not possible to predict which side of the character will develop to the larger size."

Stability of development, its "canalization", is possible thanks to homeoresis, i.e., the ability of a living organism to self-regulate the ontogenetic processes [MøLlER and SWADDLE 1997, MAYES 2001]. The mechanism of selfregulation in general boils down to keeping a constant dynamic balance between intrinsic factors of the body and the continuously varying factors of the environment. The most common cause of the disorders, however, is interference of natural mutual relations between both genetic and environmental factors during formation of particular parts of the body. Congenital factors that reduce the organism's abilities to buffer its own developmental path include: high level of inbreeding, homozygosity, hybridization (that splits up co-adapted gene complexes), novel mutations, and periods of intense directional selection [SCHARLOO 1991, OPITZ and UTKUS 2001].

The following are most commonly described indicators of developmental 
instability level: frequency of phenodeviants in a population, range of relative morphological variation of observed characters and differences in shape and structure of the repeated body elements - metameres and antimeres [RASMUSON 1960, HANDFORD 1980]. Antimeres are paired structures whose morphology is determined by the same set of genes, thus, after excluding the hereditary directional asymmetry of the characters, all anatomic differences between antimeres are considered to be an effect of the stressogenic environment. This effect is precisely reflected by variations of the fluctuating asymmetry level [THORNHILL and MøLLER 1997]. Some authors, however, state that phenotypic variance of the mean estimate of FA shows additive and non-additive (dominance) genetic components [LIVSHITS and KoBYLIANSKY 1989, 1991]. These components (even without specific "genes for FA") result from the genetically modulated expression of variation, which in itself is entirely non-genetic [POLAK 2003].

Although the mechanism of developmental buffering and control is not completely explained due to its complexity [KLINGENBERG 2002, 2003; VAN DONGEN and LENS 2002], the most common reported exogenous factors which apparently increase the level of fluctuating asymmetry of somatic characters reported from laboratory and clinic studies are the following: thermal stress, noise, malnutrition, excessive population density, chemical elements (high concentrations of mercury, copper, nickel, arsenic, DDT, fertility manufacturing waste, polyhalogenated aromatic hydrocarbons - e.g., PCBs) [MøLLER and SWADDLE 1997], as well as obesity, past infections, tobacco smoking and alcohol consumption by pregnant women, which affects the prenatal development of their children [LIVSHITS and KOBYLIANSKY 1991, KIESER et al. 1997]. In addition, individuals with genetic defects such as Down syndrome [BARDEN 1980], Martin Bell syndrome (the fragile X syndrome) [PERETZ et al. 1988], cleft lip and palate [ŻĄDZIŃSKA et al. 1999, NEISWANGER et al. 2002], as well as the mentally disabled [BARDEN 1980, MALINA and BUSCHANG 1984] and individuals suffering from alternating or constant strabismus [HEIKINNEN and ALVESAlo 2001], are affected. According to BARDEN [1980], the ability of individuals with genetic defects to buffer any stress-induced developmental instability is, in general, inhibited. Thus, monitoring of fluctuating asymmetry level is often used for assessment of environmental stressogenicity or, in the case of children with genetic defects, as a possible less invasive way of estimation of their degree of disability.

Symmetry disorders seem also to affect interpersonal attractiveness, playing an important role in partner selection [JONES 1996, SIMPSON et al. 1999, PAWŁOWSKI 2000] and to correlate with general efficiency, physical fitness [MANNING and PICKUP 1998, TOMKINSON and OLDS 2000] and even fertility [MØLLER et al. 1995, FIRMAN et al. 2003]. However, in any domain where symmetry observation is used, the portion of genetically conditioned asymmetry (directional or functional) and exogenously modified asymmetry (fluctuating) should be differentiated. It has essential scientific significance, due to their different aetiologies. 
Cephalometric characters are formed mainly during prenatal development. The head fold is visible in the embryo after about 20 days of life. After the following 2 days, the eye and ear follicles are formed. On the 24th day, the embryo has distinct ear and nose pits. After the 55th day of prenatal development the eyelids, auricles and nose are clearly visible. These morphological face structures reach their final form (but not size) and position in the head during the 16th week of fetal life. Thus, the causes responsible for disorder in the human face symmetry should be sought in the first nine months of the life. The quality of conditions of that period is indirectly assessed through child's characteristics at birth: birth weight, body length and head and chest circumferences.

The aim of this work is the assessment of the relationship between the level of biological maturity of a child, selected prenatal factors which affect the developing organism and the level of fluctuating asymmetry of the paired structures of the head.

\section{Materials and methods}

The studies involved 651 boys and 585 girls (1236 children in total) from 10 primary schools in Łódź, Poland, grades 1 to 3 , aged 7 to 10 years. The material was collected by a research team of the Chair of Anthropology of the University of Łódź during periodical monitoring of physical development of the children during 2002/03. All the paired head measurements were taken by the present author according to FARKAS [1994] procedure using the sliding or spreading caliper.

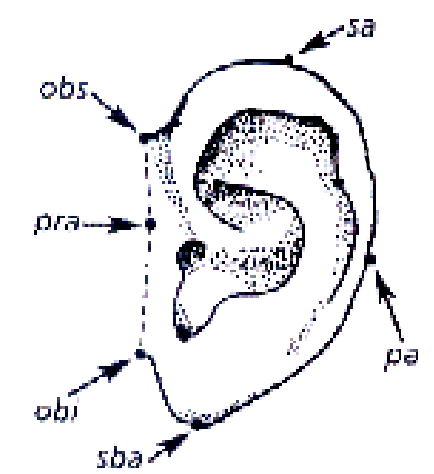

Fig. 1. Ear and its measurements used in this paper (redrawn from MALINOWSKI \& BożlŁOW [1997, p. 79]).

The following cephalometric characters were investigated: the length of the mandibular body ( $g o-g n)$, the eye fissure length (en-ex), the length of the auricle $(s a-s b a)$, the width of the auricle (pra$p a$ ), the width of the ear insertion to the head (obs-obi) (see Fig. 1), the width of the nostril base (ac-sn), the width of the ala $(a l-s n)$ and the length of the nostrils $(n a-n p)$. The examinations were carried out after positioning the subject's head in the FH (mandible, ears, eyes) or reclined position (nose). Paired measurements with one joint anthropometric point (ac-sn, al-sn and go-gn) were taken separately on the right and left side (the arms of the caliper were placed twice). The information concerning prenatal factors was derived from questionnaires filled out by parents. The birth characteristics (Tables 1-2) were completed using the child's health book. Only children who as newborns were characterized with fetal age between 34 and 42 weeks were analyzed. In the whole sample, $3.65 \%$ of newborns were too small for their gestational age (SGA) 
Table 1. Basic statistics of birth characteristics of the analyzed boys

\begin{tabular}{|c|c|c|c|c|c|c|c|c|c|c|}
\hline \multirow[b]{2}{*}{ Fetal age } & \multicolumn{2}{|c|}{ Body mass } & \multicolumn{2}{|c|}{ Body height } & \multicolumn{2}{|c|}{$\begin{array}{c}\text { Head } \\
\text { circumference }\end{array}$} & \multicolumn{2}{|c|}{$\begin{array}{c}\text { Chest } \\
\text { circumference }\end{array}$} & \multicolumn{2}{|c|}{ SI length } \\
\hline & $\overline{\mathrm{x}}$ & $s$ & $\overline{\mathrm{x}}$ & $s$ & $\overline{\mathrm{x}}$ & $s$ & $\overline{\mathrm{x}}$ & $s$ & $\overline{\mathrm{x}}$ & $s$ \\
\hline 34 & 2378.6 & 517.8 & 51.08 & 3.12 & 32.02 & 2.49 & 29.25 & 2.60 & 29.10 & 2.19 \\
\hline 35 & 2501.5 & 576.7 & 51.57 & 2.37 & 32.20 & 1.92 & 29.80 & 1.10 & 29.25 & 1.71 \\
\hline 36 & 2639.3 & 579.5 & 52.07 & 4.21 & 32.90 & 1.85 & 31.10 & 2.60 & 29.25 & 0.96 \\
\hline 37 & 3053.9 & 475.0 & 52.00 & 6.84 & 33.18 & 2.44 & 32.92 & 1.30 & 30.40 & 1.64 \\
\hline 38 & 3207.2 & 427.3 & 53.82 & 3.29 & 33.86 & 1.63 & 33.77 & 1.53 & 32.41 & 2.40 \\
\hline 39 & 3358.1 & 472.0 & 54.07 & 2.92 & 34.58 & 1.26 & 33.97 & 1.70 & 32.42 & 2.54 \\
\hline 40 & 3472.9 & 477.2 & 55.17 & 3.08 & 34.65 & 1.41 & 34.02 & 2.39 & 32.67 & 2.03 \\
\hline 41 & 3467.0 & 432.6 & 55.20 & 2.29 & 34.77 & 1.73 & 34.23 & 1.64 & 32.67 & 1.32 \\
\hline 42 & 3538.9 & 445.0 & 56.06 & 2.10 & 35.33 & 1.73 & 34.44 & 1.13 & 33.60 & 1.14 \\
\hline
\end{tabular}

Table 2. Basic statistics of birth characteristics of the analyzed girls

\begin{tabular}{lcccccccccc}
\hline & \multicolumn{2}{c}{ Body mass } & \multicolumn{2}{c}{ Body height } & \multicolumn{2}{c}{$\begin{array}{c}\text { Head } \\
\text { circumference }\end{array}$} & \multicolumn{2}{c}{$\begin{array}{c}\text { Chest } \\
\text { circumference }\end{array}$} & \multicolumn{2}{c}{ SI length } \\
\hline Fetal age & $\overline{\mathrm{x}}$ & $s$ & $\overline{\mathrm{x}}$ & $s$ & $\overline{\mathrm{x}}$ & $s$ & $\overline{\mathrm{x}}$ & $s$ & $\overline{\mathrm{x}}$ & $s$ \\
\hline 34 & 2194.4 & 547.4 & 48.22 & 4.68 & 31.14 & 1.07 & 28.14 & 2.04 & 27.01 & 4.24 \\
35 & 2342.9 & 332.2 & 49.86 & 3.93 & 31.64 & 1.11 & 28.29 & 3.68 & 29.20 & 2.51 \\
36 & 2652.9 & 590.9 & 49.59 & 3.94 & 32.56 & 1.50 & 31.13 & 2.45 & 31.00 & 1.30 \\
37 & 2826.3 & 452.3 & 52.31 & 3.29 & 33.04 & 1.37 & 31.83 & 2.08 & 31.04 & 2.48 \\
38 & 3029.0 & 444.7 & 52.89 & 3.35 & 33.45 & 2.44 & 32.67 & 1.89 & 31.17 & 1.82 \\
39 & 3179.5 & 402.3 & 53.49 & 2.64 & 33.80 & 3.08 & 33.11 & 1.56 & 31.54 & 1.85 \\
40 & 3212.8 & 451.0 & 54.03 & 2.80 & 33.98 & 1.67 & 33.28 & 2.27 & 31.84 & 2.93 \\
41 & 3386.8 & 322.4 & 54.77 & 2.27 & 34.14 & 1.24 & 33.88 & 1.09 & 32.10 & 1.91 \\
42 & 3474.6 & 412.7 & 54.86 & 2.50 & 34.78 & 1.56 & 34.01 & 1.41 & 32.50 & 1.29 \\
\hline
\end{tabular}

and $4.02 \%$ were diagnosed as IUGR newborns (Intrauterine Growth Retardation).

Differences between measurements on the right and left side of the head were assessed for each character. Distributions of calculated differences were compared to the normal distribution with the values of kurtosis and skewness given for each of them [POLAK 2003]. The variance of differences between right and left character values (R-L) were used to assess the fluctuating asymmetry level of each character and each individual [PALMER and STROBEK 1986, POLAK 2003]. In order to avoid 
the error resulting from character size (different traits and age), the standardization was performed according to the following formula:

$$
\mathrm{FA} 1=\frac{\operatorname{var}(\mathrm{R}-\mathrm{L})}{\sqrt{\operatorname{var} \mathrm{R} \cdot \operatorname{var} \mathrm{L}}}
$$

Additionally, (because of the sufficient number of the examined) FA2 was calculated as a correlation coefficient $r$ between the measurements on the right and left side of the head (the more the correlation coefficient differs from one, the higher is the fluctuating asymmetry level). By transforming the values of the (1-r) into Fisher's $z$-values, the comparable asymmetry scores were determined FA2 $=z_{(1-r)}$ [BARDEN 1980, TOWNSEND 1983].

Then, in order to estimate the association between the fluctuating asymmetry level of the child head and birth characteristics and selected prenatal factors, multiple regression was calculated, where FA (calculated for each individual as a standardized difference variation between measurements on the right and left side of the head) was a dependent variable while independent variables (explanatory) were divided into two sets: birth characteristics (birth weight, total body length and crown-rump length as well as head and chest circumferences) and stressogenic paragenetic factors (mass increase of the pregnant woman, her past diseases, number of hospital admissions, professional activity, tobacco smoking and alcohol consumption during pregnancy and, additionally, smoking by the mother after birth and by the father or other close persons during pregnancy).
For each of the investigated cephalometric characters the significance of the repeatability difference measurement [MøLLER and SWADDLE 1997] as well as the mean technical error (TEM) and reliability index [ULIJASZEK and LOURIE 1994, FIELDS et al. 1995] were estimated and taken into consideration before the presentation of the study results.

\section{Results}

In the analysis of differences between measurements on the right and left side of the head, values of mean measurement reliability indices vary between 0.951 and 0.980 , which means that more than $95 \%$ of measurement variability is caused by factors other than error of measurement.

All measurements of the nose, as well as the length of the mandibular body and the width of the auricle are consequently higher on the left side of the head. The highest values of fluctuating asymmetry, both in boys and girls, were observed for two measurements of the nose (width of the ala al-sn and length of the nostril $n a-n p$ ) and the lowest for the length of the auricle ( $s a-s b a)$ and length of the mandibular body (go-gn) (Tables 3-4, and Fig. 2). Both measurements of the ear (length and width) are statistically significantly more asymmetric in girls $(F=9.55, p<0.01 ; F=7.78$, $p<0.01$, respectively). The other investigated cephalometric traits show a higher level of fluctuating asymmetry in boys, although a statistically significant difference was observed only for the height of the ear base $(F=6.02$, $p<0.05$ ) (Table 5). 
Table 3. Characteristic of distributions of calculated differences between measurements on the right and left (R-L) side of the head - boys

\begin{tabular}{lcccccc}
\hline Trait & $\overline{\mathrm{x}}$ & $s$ & kurtosis & skewness & FA1 & FA2 \\
\hline go-gn & -1.60 & 2.44 & 1.07 & -0.18 & 0.30 & 0.15 \\
en-ex & 0.56 & 1.38 & 4.54 & 0.02 & 0.49 & 0.22 \\
sa-sba & 0.32 & 1.65 & 4.85 & 0.73 & 0.20 & 0.10 \\
pra-pa & -0.98 & 1.88 & 4.94 & -0.65 & 0.61 & 0.31 \\
obs-obi & 1.07 & 2.59 & 5.20 & -0.12 & 0.63 & 0.32 \\
ac-sn & -0.06 & 1.04 & -1.12 & 0.09 & 0.54 & 0.27 \\
al-sn & -1.00 & 1.20 & 1.14 & -0.21 & 0.77 & 0.38 \\
na- $n p$ & -0.54 & 1.03 & 1.13 & 0.08 & 0.68 & 0.34 \\
\hline
\end{tabular}

Table 4. Characteristic of distributions of calculated differences between measurements on the right and left (R-L) side of the head - girls

\begin{tabular}{lcccccc}
\hline Trait & $\overline{\mathrm{x}}$ & $s$ & kurtosis & skewness & FA1 & FA2 \\
\hline go-gn & -1.81 & 2.31 & 0.20 & 0.00 & 0.26 & 0.13 \\
en-ex & 0.69 & 1.32 & 3.22 & 0.01 & 0.44 & 0.20 \\
sa-sba & 0.66 & 2.13 & 3.75 & 0.93 & 0.39 & 0.19 \\
pra-pa & -0.69 & 1.87 & 5.31 & -0.49 & 0.68 & 0.34 \\
obs-obi & 1.42 & 2.43 & 1.93 & 0.18 & 0.55 & 0.28 \\
ac-sn & -0.16 & 1.03 & 0.74 & -0.13 & 0.51 & 0.25 \\
al-sn & -1.08 & 1.11 & 4.65 & 0.81 & 0.77 & 0.38 \\
na- $n p$ & -0.50 & 0.98 & 0.40 & -0.04 & 0.62 & 0.31 \\
\hline
\end{tabular}

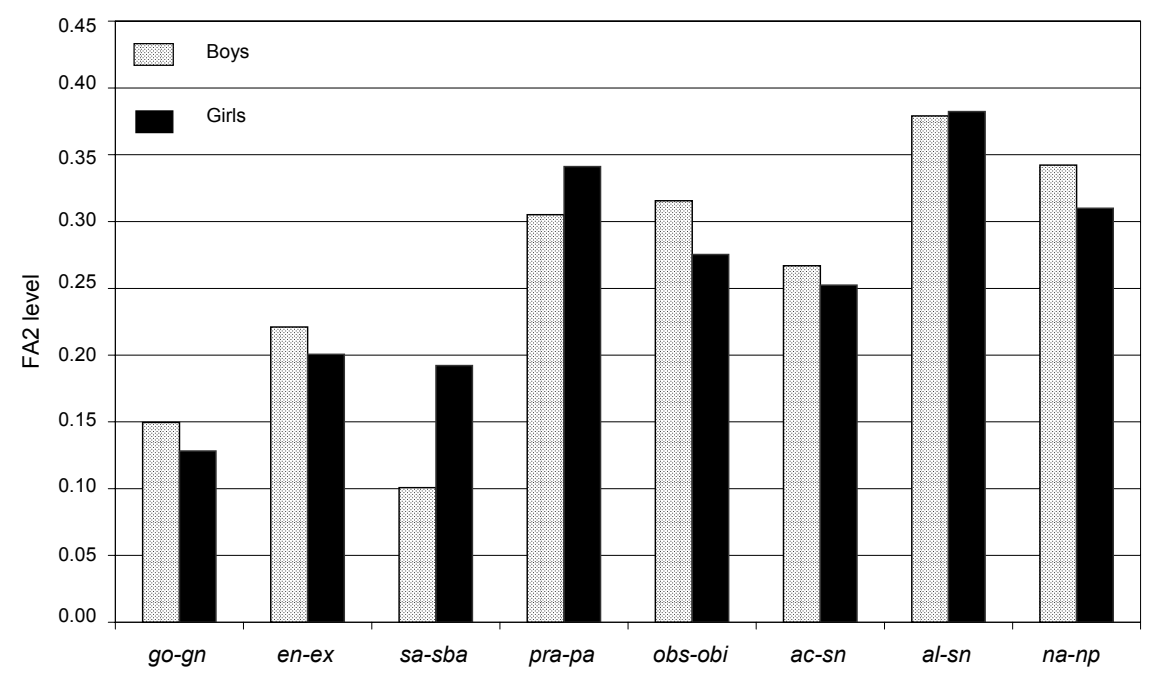

Fig. 2. Comparison of the fluctuating asymmetry level of analyzed traits in boys and girls. 
Table 5. Analysis of variance for differences in fluctuating asymmetry (FA1) level of cephalometric traits between boys and girls

\begin{tabular}{lllllc}
\hline Trait & & $N$ & FA & SE & $F$ and $p$ \\
\hline go-gn & boys & 637 & 0.30 & 0.10 & \multirow{2}{*}{$F=3.47, p=0.06$} \\
& girls & 638 & 0.26 & 0.09 & \\
en-ex & boys & 651 & 0.49 & 0.05 & $F=2.85, p=0.09$ \\
& girls & 584 & 0.44 & 0.05 & \\
sa-sba & boys & 650 & 0.20 & 0.06 & $F=\mathbf{9 . 5 5}, p=\mathbf{0 . 0 0}$ \\
& girls & 585 & 0.39 & 0.09 & \\
pra-pa & boys & 649 & 0.61 & 0.07 & $F=\mathbf{7 . 7 8}, p=\mathbf{0 . 0 1}$ \\
& girls & 585 & 0.68 & 0.08 & \\
obs-obi & boys & 651 & 0.63 & 0.10 & $F=\mathbf{6 . 0 2}, p=\mathbf{0 . 0 1}$ \\
& girls & 585 & 0.55 & 0.10 & \\
$a c-s n$ & boys & 651 & 0.54 & 0.04 & $F=3.24, p=0.07$ \\
& girls & 583 & 0.51 & 0.04 & \\
$a l-s n$ & boys & 651 & 0.77 & 0.04 & $F=2.02, p=0.16$ \\
& girls & 582 & 0.77 & 0.05 & \\
na- $n p$ & boys & 654 & 0.68 & 0.04 & $F=0.45, p=0.50$ \\
& girls & 582 & 0.62 & 0.04 & \\
\hline
\end{tabular}

The five characteristics of the biological status of the newborn (birth weight, total body length and crown-rump length as well as head and chest circumferences) taken together explain more than $4 \%$ (in case of boys) and as much as above $6 \%$ (in case of girls) of the variability of fluctuating asymmetry level of the child's head. The smaller percentage of FA variability (above 3\% in boys and below $2 \%$ in girls) is explained by the paragenetic factors taken into consideration in the present study (Tables 6-7). The relationship between the birth mass and studied asymmetry is inversely proportional. Heavier newborns have more symmetric faces during further ontogenetic stages. Similarly, a smaller birth head circumference seems to correlate with its significant asymmetry. However, an insignificant but positive correlation was observed for the chest circumferences and body length.
Considering the environmental factors affecting the prenatal development of children, the focus is on those factors that are generally recognized as disturbing fetal development and which are known to disturb body symmetry of laboratory animals: tobacco smoking and drinking of alcohol [LIVSHITS and KOBYLIANSKY 1991, KIESER et al. 1997]. Furthermore, mother's mass increase during pregnancy, her past diseases, number of hospital admissions and professional activity were also analyzed. Declared alcohol consumption by the mother and smoking of tobacco by the father show the highest correlation with the fluctuating asymmetry level, among the mentioned developmental inhibitors. On the other hand, the mother's mass increase during pregnancy, her diseases, hospital admissions and professional activity do not change the level of FA significantly. 
Table 6. Results of multiple regression analysis for birth characteristics and selected prenatal factors of the level of fluctuating asymmetry of a head - boys

\begin{tabular}{|c|c|c|c|c|}
\hline Characteristics & $b$ & SE & $t$ & $p$ \\
\hline \multicolumn{5}{|c|}{ Birth characteristics $\left(R=0.21 R^{2}=4.42 \%\right)$} \\
\hline Body mass & -0.24 & 0.06 & 3.34 & $\mathbf{0 . 0 0}$ \\
\hline Body length & 0.11 & 0.04 & 1.99 & 0.08 \\
\hline Head circumference & -0.15 & 0.05 & 2.63 & 0.01 \\
\hline Chest circumference & 0.06 & 0.06 & 1.06 & 0.22 \\
\hline SI length & 0.03 & 0.02 & 1.02 & 0.31 \\
\hline \multicolumn{5}{|c|}{ Prenatal factors $\left(R=0.18 R^{2}=3.29 \%\right)$} \\
\hline Mother's mass increase & -0.04 & 0.01 & 0.56 & 0.58 \\
\hline Number of hospital admissions & -0.09 & 0.05 & 1.20 & 0.23 \\
\hline Number of diseases & 0.04 & 0.01 & 0.49 & 0.63 \\
\hline Tobacco smoking by mother during pregnancy* & 0.14 & 0.08 & 1.72 & 0.09 \\
\hline Tobacco smoking by mother now* & 0.07 & 0.01 & 1.15 & 0.38 \\
\hline Tobacco smoking by father* & 0.23 & 0.02 & 2.47 & $\mathbf{0 . 0 3}$ \\
\hline Declared alcohol consumption by mother* & 0.29 & 0.07 & 2.80 & $\mathbf{0 . 0 3}$ \\
\hline Mother's professional activity during pregnancy* & 0.07 & 0.01 & 0.91 & 0.39 \\
\hline
\end{tabular}

* In two categories (0-no, 1-yes)

Table 7. Results of multiple regression analysis for birth characteristics and selected prenatal factors of the level of fluctuating asymmetry of a head - girls

\begin{tabular}{|c|c|c|c|c|}
\hline Characteristics & $b$ & SE & $t$ & $p$ \\
\hline \multicolumn{5}{|c|}{ Birth characteristics $\left(R=0.25 R^{2}=6.28 \%\right)$} \\
\hline Body mass & -0.25 & 0.04 & 2.65 & 0.02 \\
\hline Body length & 0.10 & 0.11 & 1.07 & 0.29 \\
\hline Head circumference & -0.18 & 0.04 & 2.56 & $\mathbf{0 . 0 3}$ \\
\hline Chest circumference & 0.16 & 0.10 & 1.52 & 0.13 \\
\hline SI length & 0.14 & 0.12 & 1.36 & 0.18 \\
\hline \multicolumn{5}{|c|}{ Prenatal factors $\left(R=0.13 R^{2}=1.76 \%\right)$} \\
\hline Mother's mass increase & 0.00 & 0.00 & 0.01 & 0.89 \\
\hline Number of hospital admissions & -0.05 & 0.07 & 0.62 & 0.54 \\
\hline Number of diseases & 0.02 & 0.01 & 0.34 & 0.73 \\
\hline Tobacco smoking by mother during pregnancy* & 0.10 & 0.01 & 1.09 & 0.10 \\
\hline Tobacco smoking by mother now* & 0.07 & 0.01 & 1.17 & 0.37 \\
\hline Tobacco smoking by father* & 0.17 & 0.07 & 2.91 & 0.01 \\
\hline Declared alcohol consumption by mother* & 0.12 & 0.01 & 2.30 & 0.04 \\
\hline Mother's professional activity during pregnancy* & 0.10 & 0.07 & 1.38 & 0.17 \\
\hline
\end{tabular}

* In two categories (0-no, 1-yes) 


\section{Discussion}

It is difficult to precisely isolate the fluctuating asymmetry from the whole asymmetry typical for a given character, observed either at the population or the individual level, without complicated statistical operations. However, the procedures are necessary since only values of the fluctuating asymmetry level provide information of the power of the factors disturbing the development (including organogenesis and growth of paired elements) and efficiency of mechanisms (individual or populational) which buffer these disorders [e.g., MøLLER and SWADDLE 1997, OPITZ and UTKUS 2001].

The prevalence of the five face measurements taken on the left side (the length of the mandibular body, the width of the auricle as well as all measurements of nose) confirm the earlier analysis conducted by MALINOWSKI and LOSIAK [1974], who found that some face arches on the left side of the head were larger than those on the right side.

In this study, among the analyzed anthropometric characters, the highest level of fluctuating asymmetry was observed for nose measurements. Noticeable differences between the fluctuating asymmetry level of characters, both somatometric and cephalometric, within the same population are often observed [LIVSHITS et al. 1998, TOMKINSON et al. 2003]. These differences may result from the duration of the characters' formation - characters, which take longer to develop and are theoretically exposed for longer to disturbing factors [OPITZ \& UTKUS 2001]. According to the study of APARICIO and BONAL [2002], characters of less complex structure seem also to be more asymmetric. This may also depend on the initial developmental stage of paired characters. The characters begin their growth from certain levels of symmetry and structural stability that vary while buffering the effects of environmental "noise" during ontogenesis [APARICIO 1998, 2001]. On the other hand, according to the alternative idea, the paired characters begin their development from asymmetry, which is reduced during ontogenesis due to the congenital self-regulating mechanism [HALLGRIMSSON et al. 2003]. However, the cellular stage of development is very important in both cases.

In the case of humans, the first pair of somites is formed from para-axial mesoderm as early as the 20th day of embryonic development [BARTEL 2002]. At the end of the 8th week of prenatal life all the essential child's facial structures are formed. During the following developmental stages, changes are noticed in the proportions between particular face parts and their size and shape. According to O'RAHILLY and MÜLLER [1987], every structure has a critical period during embryogenesis during which the possibility of disturbing and the appearance of pathology of its developmental process is considerably increased. For the ears, this period lasts about 8 weeks (from 4th to 11 th), for the eyes 5 weeks (3.5-8.5), for the nose 4 weeks (4-7) and for the mandible 7 weeks (4-10).

The face characters analyzed in this paper are made up of distinct elements. Each develops and grows under the influence of diverse local and systemic factors. Some of them are nearly purely cartilaginous, others are characterized 
by intramembranous ossification, while some others are basically cutaneous. Different tissues can be variously affected by stressogenic factors during their development. The rate of postnatal growth can be also important. According to FARKAS and HRECZKO [1994], different measurements of the craniofacial complex reach high but different percentages of their developmental level in children at one year of age, e.g. the width of the ear $-93.5 \%$, the eye fissure height $-86.5 \%$, the eye fissure length $82.7 \%$, the width of the nose $-79.5 \%$, the length of the ear $-76.4 \%$ and the width of the mandible $-76.2 \%$. In addition, the plasticity of a character at its maximal development [APARICIO 1998], as well as its functional or selective suitability, seem to be important factors [BALMFORD et al. 1993, MøLLER and SWADDLE 1997].

The difference between the sexes in the fluctuating asymmetry levels of head measurements was statistically significant for three investigated characters: height and width of the auricle (higher FA values were observed in girls) and height of the ear base (higher FA values were observed in the boys). The direction of the sexual dimorphism of the fluctuating asymmetry in vertebrates described in the literature differs. However, male individuals usually show higher level of the fluctuating asymmetry [APARICIO and BONAL 2002] which is often linked to their higher ecosensitivity. It is also important to determine whether a given character plays an important role in sexual selection [BJORKSTEN et al. 2000, PAWŁOWSKI 2000]. The higher sensitivity of boys to environmental conditions may be confirmed by the fact that the investigated set of paragenetic factors for boys shows a twice greater percentage of FA variability of the head than for girls.

The birth characteristics indicate the biological maturity of the newborn thus they reflect, to some extent, regularity of the aforementioned homeorhesis mechanisms during prenatal development. Birth mass, in particular, is important, as it is modified by intrauterine environment much strongly than the body length and circumferences, for which genetic determination seems to be essential [KORNAFEL 1995]. Thus, the apparent negative correlation between birth mass and the fluctuating asymmetry level of the head may confirm the fact that fetal and birth body mass is a good indicator of biological maturity of the body (including its ability to stabilize its development) which is modified both by genetic and non-genetic factors. On the other hand, positive corelation between chest circumference and head asymmetry may be surprising. However, according to HELMS and SCHNEIDER [2003], the molecular mechanisms that initiate and control chondrogenesis and osteogenesis of the cranial skeleton are different from those responsible for similar processes within the postcranial skeleton. Although the growth factors (epidermal - EGF, transforming - TGF and colony-stimulating - CSF) are mobilized in both cases, the chain of molecular signals which initiates their cascade secretion is read differently in the cells forming the head structures from that in the cells which later form the postcranial skeleton. It is also worth considering whether "large" has to mean "symmetric". KORNAFEL [1995], investigating birth size of the child, noticed that larger sizes of fetuses and newborns 
do not, in fact, have to be advantageous for their further development.

Moderate alcohol consumption by a pregnant woman (women addicted to alcohol were excluded from the study), normally considered not to affect the fetus [KARINIEMI and ROSTI 1988], actually disturbed the head symmetry, thus corroborating some previous studies [LIVSHITS and KOBYLIANSKY 1991, KIESER et al. 1997]. It is also interesting, that tobacco smoking by the father (or a person from the closest surroundings) during prenatal development may disturb the developmental stability of cranial structures more than declared nicotine use by the future mother herself. Tobacco smoke (passive smoking) is considered a dangerous stressogenic factor [RUBIN et al. 1986, DRÓŻDŻ et al. 1988]. This result also could be an effect of methodology - the information concerning prenatal factors was derived from a questionnaire filled out by parents. Nonetheless, it may still be easier for the mother to say that it was only her partner who had been smoking during her pregnancy [BIEŃKIEWICZ 1986]. The questions did not specify an exact period of tobacco smoking during pregnancy. This omission could be important, because the "sensibility" of head structures varies during developmental stages of the human embryo [O'RAHILLY and MÜLLER 1987].

The birth parameters and investigated paragenetic factors explain about $8 \%$ of total variability of the fluctuating asymmetry level of the head. However, one should remember that the stimulation of developmental processes is an extremely complex phenomenon involving many more factors than the ones described here. Thus, it seems prudent to update the database with subsequent development stimulators.

It is also possible that the FA variability (the plasticity range of the body in modifying it) is, to some degree, genetically determined, as recent studies suggest [HALLGRIMSSON et al. 2003, POLAK 2003]. During development, the molecular mechanisms lead to the construction of complex morphological structures. This dynamic process can also be characterized as a sort of normal morphological "noise". The patterns of FA observed in morphological traits may be a "by-product" of the degree of development and cost of growth, regardless of the mode of selection, individual quality or levels of developmental stability [APARICIO 2001]. Such a model could provide the explanation for about $92 \%$ of variance observed in FA. Therefore, fluctuating asymmetry of human cephalometric characters is a phenomenon that is not definitely selected and, as such, warrants further investigation.

\section{Acknowledgements}

I am very grateful to Professor Maciej Henneberg for his patience and methodological support. I also thank the referees for their valuable comments.

\section{References}

APARICIO J.M., 1998, Patterns of fluctuating asymmetry in developing primary feathers: A test of the compensational growth hypothesis, Proc. R. Soc. Lond. B., 265, 2353-57

ApARICIO J.M., 2001, Patterns of growth and fluctuating asymmetry: The effects of asymmetrical investment in traits with determinate growth, Behav. Ecol. Sociobiol., 49, 273-82 
APARICIO J.M., R. BONAL, 2002, Why do some traits show higher fluctuating asymmetry than others? A test of hypotheses with tail feathers of birds, Heredity, 89, 139-44

BALmFord A., I.L. Jones, A.L.R. Thomas, 1993, On avian asymmetry: Evidence of natural selection for symmetrical tails and wings in birds, Proc. R. Soc. Lond. B., 252, 245-51

BARDEN A., 1980, Fluctuating dental asymmetry: $A$ measure of developmental instability in Down syndrome, Am. J. Phys. Anthropol., 52, 169-73

BARTEL H., 2002, Embriologia, Wyd. Lek. PZWL, Warszawa

BIEŃKIEWICZ L., 1986, Wpływ palenia papierosów przez rodziców na stan noworodka, Prz. Ped., 16, 9-16

Bjorksten T.A., P. DAwid, A. Pomiankowski, K. FOWLER, 2000, Fluctuating asymmetry of sexual and nonsexual traits in stalkeyed flies: A poor indicator of developmental stress and genetic quality, J. Evol. Biol., 13, 89-97

DANGERFIELD P.H., 1994, Asymmetry and growth, [in:] Anthropometry: The individual and the population, S.J. Ulijaszek \& C.G. Mascie-Taylor (eds.), Cambridge Univ. Press, Cambridge, pp. 7-29

DRÓŻDŻ M., Z. STRZELCZAK, A. JENDRYCZKO, 1988, Palenie papierosów $i$ palenie bierne $w$ czasie ciaży $i$ po porodzie, Gin. Pol., 59, 528-32

FARKAS L.G., 1994, Examination, [in:] Anthropometry of the head and face, L.G. Farkas (ed.), Raven Press, New York, pp. 3-56

FARKAS L.G., T.A. HRECZKO, 1994, Age-related changes in selected linear and angular measurements of the craniofacial complex in healthy North American Caucasians, [in:] Anthropometry of the head and face, L.G. Farkas (ed.), Raven Press, New York, pp. 89102

FIEldS S.J., M. SPIERS, I. HeRSHKOVITZ, G. LIVSHITS, 1995, Reliability of reliability coefficients in the estimation of asymmetry, Am. J. Phys. Anthropol., 96, 83-87

Firman R.C., L.W. Simmons, J.M. Cummins, P.L. MATSON, 2003, Are body fluctuating asymmetry and the ratio of $2^{\text {nd }}$ to $4^{\text {th }}$ digit length reliable predictors of semen quality?, Hum. Reprod., 18(4), 808-12

Fudali M., G. GRAlla, 1972, Asymetria $w$ wielkości kości dtugich wczesnośredniowiecznych Miliczan, Prz. Antropol., 38, 27-37
GELlon G., W. MC GINNIS, 1998, Shaping animal body plans in development and evolution by modulation of Hox expression patterns, BioEssays, 20, 116-25

Hallgrímsson B., T. Miyake, K. Wilmore, B.K. HALL, 2003, Embryological origins of developmental stability: Size, shape and fluctuating asymmetry in prenatal random bred mice, J. Exp. Zool. (Mol. Dev. Evol.), 296B, 40-57

HANDFORD P., 1980, Heterozygosity at enzyme loci and morphological variation, Nature, 286, 261-62

Heikkinen T., L. Alvesalo, 2001, Permanent tooth crown size and asymmetry in children with strabismus, [in:] Dental Morphology, Sheffield Acad. Press, Sheffield, pp. 21-336

Helms J.A., R.A. SCHNEIDER, 2003, Cranial skeletal biology, Nature, 423, 326-31

Henneberg M., 1974, Próba znalezienia metody badania i interpretacji asymetrii kości dtugich kończyn, Prz. Antropol., 40, 113-26

JONES D., 1996, An evolutionary perspective on physical attractiveness, Evol. Anthropol., 5, 97-109

KARINIEMI V., J. RosTI, 1988, Maternal smoking and alcohol consumption as determinants of birth weight in an unselected study population, J. Perinat. Med., 16, 249-52

Kieser J.A., H.T. Groeneveld, P.C.F. DA SILVA, 1997, Dental asymmetry, maternal obesity, and smoking, Am. J. Phys. Anthropol., 102, 133-39

KLingenberg C.P., 2002, A developmental perspective on developmental instability: Theory, models and mechanisms, [in:] Developmental instability: Causes and consequences, M. Polak (ed.), Oxford Univ. Press, New York, pp. 14-34

KLINGENBERG C.P., 2003, Fluctuating asymmetry and animal welfare: How far are we? And how far should we go?, Vet. J., 166, 5-6

KORNAFEL D., 1995, Czynniki determinujace urodzeniowa mase ciała człowieka, Wyd. UWr, Wrocław

Livshits G., E. KobYliansky, 1989, Study of genetic variance in the fluctuating asymmetry of anthropometrical traits, Ann. Hum. Biol., 16, 121-29

Livshits G., E. KoBYLIANSKY, 1991, Fluctuating asymmetry as a possible measure of developmental homeostasis in humans: A review, Hum. Biol., 63, 441-66 
Livshits G., K. YakovenKo, L. Kletselman, D. KARASIK, E. KoBYLIANSKY, 1998, Fluctuating asymmetry and morphometric variation of hand bones, Am. J. Phys. Anthropol., 107, 125-36

Malina R.M., P.H. Buschang, 1984, Anthropometric asymmetry in normal and mentally retarded males, Ann. Hum. Biol., 11, 515-31

Malinowski A., W. BożıŁow, 1997, Podstawy antropometrii. Metody, techniki, normy, Wyd. Nauk. PWN, Warszawa-Łódź

MALINOWSKI A., B. LosiAK, 1974, Asymetria twarzy $w$ świetle pomiarów tuków tragionnasion, tragion-subnasale $i$ tragion-gnathion, Prz. Antropol., 40, 127-32

MAnNing J.T., L.J. PICKUP, 1998, Symmetry and performance in middle distance runners, Int. J. Sport. Med., 19, 205-09

MAYES L.C., 2001, The twin poles of order and chaos. Development as a dynamic, selfordering system, Psychoanal. Study Child., 56, 137-70

Mizoguchi Y., 1988, Degree of bilateral asymmetry of nonmetric tooth crown characters quantified by the tetrachoric correlation method, Bull. Nat. Sci. Mus. Tokyo, Ser. D., 14, 29-49

Mizoguchi Y., 1990, Covariation of asymmetries in metric and nonmetric tooth crown characters, Bull. Nat. Sci. Mus. Tokyo, Ser. D., 16, 39-47

Møller A.P., J. MANNING, 2003, Growth and developmental instability, Vet. J., 166(1), 19-27

Møller A.P., M. Soler, R. ThORNhill, 1995 , Breast asymmetry, sexual selection, and human reproductive success, Ethnol. Sociobiol., 16, 207-19

Møller A.P., J.P. SwADDle, 1997, Asymmetry, developmental stability, and evolution, Oxford Univ. Press, New York

Neiswanger K., M.E. CoOPER, S.M. WeInBERG, et al., 2002, Cleft lip with or without cleft palate and dermatoglyphic asymmetry: Evaluation of a Chinese population, Orthod. Craniofac. Res., 5, 140-46

Nunes F.D., F.C.S. DE AlmeIDA, R. TuCCI, S.C. DE SousA, 2003, Homeobox genes: A molecular link between development and cancer, Pesqui. Odontol. Bras., 17(1), 94-98

OpITZ J.M., A. UTKus, 2001, Comments on biological asymmetry, Am. J. Med. Genet., 101, 359-69
O’Rahilly R., F. Müller, 1987, Developmental stages in human embryos, Carnegie Institution of Washington, Washington, Publ., 67

Palmer A.R., C. Strobeck, 1986, Fluctuating asymmetry: Measurement, analysis, patterns, Ann. Rev. Ecol. Syst., 17, 391-21

Peretz B., P. Ever-Hadani, P. Casamassimo, E. Eidelman, C. Shellhart, R. Hagerman, 1988, Crown size asymmetry in males with fra(x) or Martin-Bell syndrome, Am. J. Med. Genet., 30, 185-90

PAWŁOWSKI B., 2000, The biological meaning of preferences on the human mate market, Prz. Antropol.-Anthropol. Rev., 63, 39-72

POLAK M., 2003, Developmental instability. Causes and consequences, Oxford Univ. Press, New York

RASMUSON M., 1960, Frequency of morphological deviations as a criterion of developmental stability, Hereditas, 46, 511-36

Rubin D.H., P.A. KrasilnikofF, J.M. LeVENTHAL, B. Weile, A. BERGET, 1986, Effect of passive smoking on birth-weight, Lancet, 2, 415-17

Scharloo W., 1991, Canalization: Genetic and developmental aspects, Ann. Rev. Ecol. Syst., 22, 65-93

Simpson J.A., S.W. GANGESTAD, P.N. ChrisTENSEN, K. LECK, 1999, Fluctuating asymmetry, sociosexuality, and intrasexual competitive tactics, J. Person. Soc. Psych., 76, 159-72

TABIN C.J., A.P. MCMAHON, 1997, Recent advances in Hedgehog signalling, Trends Cell Biol, 7, 442-47

Thornhill R., A.P. Møller, 1997, Developmental stability, disease and medicine, Biol. Rev., 72, 497-548

Tomkinson G.R., T.S. OLds, 2000, Physiological correlates of bilateral symmetry in humans, Int. J. Sports Med., 21, 545-50

Tomkinson G.R., N. Popović, M. Martin, 2003, Bilateral symmetry and the competitive standard attained in elite and sub-elite sport, J. Sports Scien., 21, 201-11

TOWNSEND G.C., 1983, Fluctuating dental asymmetry in Down's syndrome, Austr. Dent. J., 28, 39-44

UliJASZEK S.J., J.A. LOURIE, 1994, Intra- and inter-observer error in anthropometric measurement, [in:] Anthropometry: The individual and the population, S.J. Ulijaszek \& C.G.N. Mascie-Taylor (eds.), Cambridge Univ. Press, Cambridge, pp. 30-55 
VAn Dongen S., L. Lens, 2002, Modelling developmental instability as the joint action of noise and stability: A Bayesian approach, BioMed Central Evol. Biol., 19, 1-11

ŻĄDZIŃSKA E., B. LUBOWIEDZKA, B. ANTOSZEWSKI, 1999, Zmienna asymetria (FA) uzębienia $u$ dzieci $z$ zespotem Downa $i$ rozszczepem podniebienia, [in:] Streszczenia Ogólnopolskiej Konferencji Naukowej PTA „Antropologia u schyłku wieku”, Warszawa - Rynia, pp. 161-62

\section{Streszczenie}

Pomimo precyzji mechanizmów molekularnych, zapewniających jednakowy rozwój prawej i lewej strony ciała, struktury parzyste prawie nigdy nie są doskonale symetryczne, lecz wykazują pewien stopień asymetrii, na którą składają się asymetria kierunkowa i fluktuacyjna oraz, niezwykle rzadko, antysymetria. Asymetria kierunkowa występuje wtedy, gdy różnice pomiędzy cechą z prawej i lewej strony ciała (P - L) wykazują stały kierunek, a ich rozkład w populacji charakteryzuje się wyraźną skośnością. Odmienną etiologią charakteryzuje się asymetria zmienna - fluktuacyjna (FA). Nieznaczne odchylenia od symetrii (rozkład różnic pomiędzy pomiarami z lewej i prawej strony ciała nie odbiega w sposób statystycznie istotny od zera) nie wykazują określonego kierunku.

Podwyższony poziom asymetrii fluktuacyjnej struktur parzystych uznawany jest za efekt negatywnego oddziaływania czynników egzogennych na rozwijający się organizm. Zależy on nie tylko od rodzaju, nasilenia i czasu trwania czynnika stresogennego, lecz także od indywidualnych zdolności osobnika do stabilizacji rozwoju w warunkach dla niego niekorzystnych. Do najczęściej opisywanych mierników poziomu destabilizacji rozwoju należą różnice w budowie i kształcie powtarzających się elementów ciała [RASMUSON 1960, HANDFORD 1980], np. struktury parzyste, których morfologia determinowana jest przez jeden zestaw genów. Po wykluczeniu dziedzicznej asymetrii kierunkowej tych cech, wszelkie odmienności anatomiczne są uznawane za efekt stresogenności środowiska zewnętrznego i odzwierciedlają się w asymetrii fluktuacyjnej. Przyczyn zaburzeń w symetrii ludzkiego ciała należy zatem szukać w ciągu pierwszych dziewięciu miesięcy życia. Jakość warunków tego okresu pośrednio oceniana jest poprzez parametry urodzeniowe dziecka: masę i długość ciała oraz obwody głowy i klatki piersiowej.

Celem pracy jest ocena zależności pomiędzy stanem dojrzałości biologicznej dziecka oraz wybranymi czynnikami paragenetycznymi, oddziałującymi na rozwijający się organizm dziecięcy $-\mathrm{z}$ jednej strony, a poziomem asymetrii fluktuacyjnej wybranych struktur morfologicznych głowy - z drugiej. Badaniami objęto 651 chłopców i 585 dziewcząt z 10 szkół podstawowych Łodzi z klas I-III w wieku od 7 do 10 lat. Przeanalizowano następujące parzyste cechy kefalometryczne: długość trzonu żuchwy (go-gn), szerokość szpary ocznej (en-ex), wysokość małżowiny usznej ( $s a-s b a)$, szerokość małżowiny usznej (pra-pa), wysokość nasady ucha (obs-obi) (Rys. 1), szerokość nasady nosa (ac-sn), szerokość skrzydełek nosa $(a l-s n)$ oraz długość otworów nosowych (na-np) [FARKAS 1994].

Przy ocenie poziomu asymetrii zmiennej każdej z cech oraz poszczególnych osobników posłużono się standaryzowaną wariancją różnic w pomiarach pomiędzy prawą a lewą stroną głowy oraz dodatkowo (ze względu na wystarczająca liczebność badanych) współczynnikiem korelacji. W celu oszacowania związku pomiędzy poziomem asymetrii fluktuacyjnej głowy dziecka a parametrami urodzeniowymi (Tab. 1-2) i wybranymi czynnikami paragenetycznymi przeprowadzono analizę regresji wielokrotnej, gdzie oznaczono następujące zmienne: zmienną zależną - FA (liczoną dla każdego osobnika jako standaryzowana wariancja 
różnic pomiędzy prawymi i lewymi pomiarami głowy) oraz zmienne niezależne (objaśniające) w dwu zestawach: parametrów urodzeniowych (masa ciała, długość ciała całkowita i siedzeniowa, obwód głowy i klatki piersiowej) oraz stresogennych czynników paragenetycznych (przyrost masy ciała ciężarnej, przebyte przez nią schorzenia, ilość hospitalizacji, aktywność zawodowa, palenie papierosów i spożywanie alkoholu podczas ciąży, oraz dodatkowo palenie papierosów przez matkę po porodzie i przez ojca w trakcie trwania ciąży).

Najwyższe wartości asymetrii fluktuacyjnej zarówno u chłopców, jak i dziewcząt zanotowano dla dwóch pomiarów nosa (szerokości skrzydełek nosowych al-sn oraz długości otworów nosowych $n a-n p)$, najniższe zaś dla wysokości małżowiny usznej ( $s a-s b a)$ oraz długości trzonu żuchwy (go-gn) (Tab. 3-4, Rys. 2). Obydwa pomiary małżowiny usznej (wysokość i szerokość) są w sposób statystycznie istotny bardziej asymetryczne u dziewcząt. Pozostałe analizowane cechy kefalometryczne charakteryzują się wyższym poziomem asymetrii fluktuacyjnej wśród chłopców, choć statystycznie istotne różnice zanotowano jedynie dla wysokości nasady ucha (Tab. 5).

Parametry stanu biologicznego noworodka jako kompleks pięciu cech (masa oraz długość ciała całkowita i siedzeniowa, obwód klatki piersiowej i głowy) razem wyjaśniają w przypadku chłopców ponad $4 \%$, a w przypadku dziewcząt aż ponad $6 \%$ zmienności poziomu asymetrii fluktuacyjnej głowy dziecka. Mniejszy procent zmienności FA (ponad 3\% u chłopców i niecałe $2 \%$ u dziewcząt) objaśniają brane pod uwagę w niniejszym opracowaniu czynniki paragenetyczne (Tab. 6-7). Zależność pomiędzy masą ciała noworodka a badaną asymetrią jest odwrotnie proporcjonalna. Cięższe noworodki charakteryzują się bardziej symetryczną twarzą na dalszych etapach ontogenezy. Mniejszy urodzeniowy obwód głowy wydaje się korelować z jej znaczniejszą asymetria. Nieznaczna, lecz dodatnią korelację zaobserwowano natomiast dla obwodu klatki piersiowej i długości ciała. Wśród wymienionych stymulatorów rozwoju, z poziomem asymetrii fluktuacyjnej najbardziej koreluje deklarowane spożycie alkoholu przez matkę oraz palenie papierosów przez ojca. Nie zmienia go natomiast znacząco przyrost masy ciała matki w czasie ciąży oraz jej hospitalizacja, schorzenia i aktywność zawodowa. 